\title{
Experience in Implementing a Practice-Oriented Programme for Re- training Mediators for Education and the Social Sphere
}

\author{
Vera V. Korshunova* and Elena A. Birkun \\ Siberian Federal University \\ Krasnoyarsk, Russian Federation
}

Received 25.06.2020, received in revised form 04.09.2020, accepted 08.09.2020

\begin{abstract}
The relevance of the present study is confirmed by an order for retraining specialists for education and the social sphere who can act as mediators and form a culture of peaceful conflict resolution in a multicultural environment. The article analyses and highlights employers' demands for the mediation competence formation among the participants of the educational space of the Krasnoyarsk Krai.

In this context, the authors disclose practical aspects of the mediation competence formation in the process of professional training of future mediators and specialists of school mediation services at the federal university.

Based on the analysis of specific features of mediators professional activity, the results of a survey of specialists in the social sphere, as well as experience of training students majoring in pedagogy at the federal university, a model of a practice-oriented programme for retraining mediators for education and the social sphere of the Krasnoyarsk Krai has been proposed. The programme is implemented on the basis of the Centre for Mediation in Education of the School of Education, Psychology and Sociology of Siberian Federal University, in the networking between educational organisations and professional communities. The retraining programme considers the needs of the multinational Siberian society and is aimed at solving regional problems in education and the social sphere.

The retraining programme is based on the principles of continuity, professional activity supervision, eventfulness of the educational process, professional activity tests, as well as continuity of the results of formal and non-formal education.

Future mediators training within the framework of the retraining programme "Mediation. The Psychology of Conflict Management" is carried out according to a modular curriculum, in which the proportion of practical classes is increased, students' scientific and research activities on the issues of productive communication in a mediation procedure are organised, and professional tests are carried out within the framework of placement practice.

To form the applied aspects of the professional competence of future mediators and specialists of school mediation services, representatives of network partners take part in the educational process.
\end{abstract}

\footnotetext{
(C) Siberian Federal University. All rights reserved

* Corresponding author E-mail address: wera7@mail.ru ORCID: 0000-0002-2042-2417 (Korshunova)
} 
The applied aspects of training future mediators and specialists of school mediation services among teachers help to effectively solve professional tasks of organising a conflict-free educational space and contribute to the formation of the culture of productive communication and conflict resolution.

The mediation competence formation among the educational process participants was carried out using methods of measuring communicative, information and analytical, organisational and managerial, as well as emotional competences.

The study was conducted with the use of Google services in the period of 2019-2020. In total, 333 people took part in the study, including 238 practicing specialists of school mediation services (control group), and 95 master's students of the School of Education, Psychology and Sociology of Siberian Federal University in Krasnoyarsk and students of the professional retraining programme "Mediation. The Psychology of Conflict Management" (experimental group).

Keywords: mediation, competence, mediation competence, professional development of a mediator, retraining, conflict resolution, reflection, applied aspect, practice-oriented programme.

The material was prepared within the framework and sponsorship of the project powered by the Russian Foundation for Basic Research (RFFR). No. 18-013-00528 "The Study of Mediation Practices in the Field of Education for Harmonisation of Interethnic Relations in A Multicultural Environment".

Research area: education.

Citation: Korshunova, V.V., Birkun, E.A. (2020). Experience in implementing a practice-oriented programme for retraining mediators for education and the social sphere. J. Sib. Fed. Univ. Humanit. Soc. Sci., 13(9), 1466-1480. DOI: 10.17516/1997-1370-0656.

\section{Introduction}

Socio-cultural changes in modern society are focused on the formation of skills for productive interaction and the ability to live in a multinational society. At the same time, there is a process of weakening the position of the institution of family in society, which significantly hinders successful socialisation of children.

In this regard, functions of socialisation and adaptation of children to the conditions of a changing world, as well as acquisition of experience of behaviour in conflict situations and formation of the ability to prevent, peacefully resolve and predict the consequences of a conflict are transferred to educational organisations. This is enshrined in the Federal State Educational Standard in terms of the requirements for the personal development results of students as a component of the communicative competence for conflict resolution.
The Krasnoyarsk Krai school students are characterised by national and religious differences, a variety of social statuses, upbringing and cultural traditions, as well as specific features of personal self-identification. These differences are sources of conflicts. Educational organisations have adopted rules for teachers' response to students' conflicts with each other, with teachers and staff, as well as with parents. Administrative actions are still the most common way to resolve conflicts, but these actions do not always resolve, but sometimes aggravate the situation. There is a real need for professional mediators who know the technologies for peaceful resolution of social, interethnic, intercultural, and interpersonal conflicts.

Any educational organisation is a potentially conflict environment. Mediators in education and the social sphere are not only organisers of the procedures for resolving conflicts, 
they are meant to contribute to the creation of a conflict-free educational environment, to take part in the processes of personal development and fostering a culture of constructive behaviour of the educational process subjects in a conflict situation.

To take professional actions, a mediator needs to have pedagogical skills and a number of key competencies, which include organisational, communicative, conflictological, multicultural, mediation, etc.

In this regard, mediation services, which mission is to prevent conflicts and the optimal use of methods for resolving them, have begun to be created in Russian schools (Order No. 1618-p. of August 8, 2014, 2014).

The use of mediation technologies in working with minors in the Krasnoyarsk Krai is one of the priority directions in the development of the early crime prevention system. The leading target is the attitude towards mediation as a constructive way of resolving conflicts in the interests of children and their families.

Since 2010, mediation services in the general education system of the Krasnoyarsk Krai have been organised in the format of pilot projects of educational organisations, including internship venues. Such projects are being implemented on the basis of Gymnasia No. 7 in Krasnoyarsk, the Centre for Upbringing and Civic Education of the Krasnoyarsk Regional Institute for Advanced Training of Teaching Staff, as well as on the basis of MBGEI "Secondary School No. 95" of closed town Zheleznogorsk. School mediation services are created with the cooperation of socially oriented non-for-profit organisations. In 2018, the educational institutions of the Krai started the process of forming school mediation services as an alternative to administrative methods of preventing delinquent behaviour of adolescents and constructively resolving conflicts in the interests of children and their families. Conditions for improvement of the social and communicative competences of the educational relations' participants, implementation of a mediated approach and the use of conscious positive communication skills to prevent and effectively resolve disputes and conflicts, are being created in the educational organisations of the Krai.

As at the beginning of 2020, School Mediation Services were created in 116 educational organisations of Krasnoyarsk, but monitoring data indicate that there is an acute shortage of qualified specialists who can competently use mediation procedures in education and the social sphere.

The real situation with forecasting the demand for mediators for the education system and the social sphere in the labour market is even more complicated.

This is primarily connected to the fact that teaching staff do not completely understand the importance of using mediation technologies and do not strive to master the skills of productive interaction and conflict-free communication, mentioning heavy workload and lack of financial incentives. School psychologists, who are entrusted with organising the activities of mediation service are left alone with numerous serious problems of students, while they do not have sufficient tools for productive work and do not know mediation technologies in education and the social sphere.

Thus, according to the results of monitoring the activities of mediation services ${ }^{1}$ operating in educational institutions of the municipality, in the first half of 2020 the number of mediators in the education system and the social sphere is 270 people, but only 161 of them systematically carry out mediation procedures, and 109 carry out other activities (educational work and psychological consulting).

Based on the analysis of data from monitoring the activities of school mediation services, it can be noted that $10 \%$ of specialists do not have mediation competence and, therefore, they do not have an opportunity to use mediation procedures in education and the social sphere effectively.

Based on the forecast of the victimological tension of the modern society, the Krasnoyarsk Krai is in one of the zones of maximum vulnerability, located at the intersection of migration flows. The Krasnoyarsk Krai is distinguished by its specific features determined

\footnotetext{
Interregional Public Centre "Judicial and Legal Reform". Available at: http://sprc.ru (accessed: August, 7, 2020).
} 
by the uniqueness of natural and geographical conditions, differences in culture, way of life and behaviour of its multinational population. The modern sociocultural situation in the Krasnoyarsk Krai is characterised by specific political, economic, socio-cultural and technological trends (Andronnikova, Radzikhovskaya, 2020). Krasnoyarsk is a large, intensively developing economic, educational, and cultural centre, a space of post-industrial development, as well as a place for attracting young people. As one of its strategic directions, the regional education system provides for the renewal of the content of higher professional education and retraining programmes to ensure the formation of the mediation competence of pedagogical and managerial staff to create and ensure a conflict-free educational environment.

\section{Statement of the problem}

Issues of interethnic and interpersonal relations, the practice of cultures interaction, awareness of oneself as a subject of culture through the unity of ideas and knowledge about the originality of different cultures are relevant for the educational environment of the Krasnoyarsk Krai.

The issue of the need to retrain teaching staff for the regional education system as mediators who are ready for constructive conflicts resolution and pronounced abilities to perceive and comprehend the phenomena of a multicultural society in education and the social sphere becomes quite acute.

An important priority in training mediators for education and the social sphere is to focus on the formation of multicultural and mediation competencies of future specialists, capable of developing interethnic and intercultural contacts during the implementation of educational events.

It is possible to distinguish general principles in the field of training specialists for school mediation services, which are focused on the study of theoretical aspects, rules, and principles of mediation. It is worth noting the importance of the applied aspect of training mediators for the social sphere, their professional orientation to the development of alternative technologies for disputes resolution, understanding the role of a mediator in negotiations. In this regard, mastering a new type of professional activity of a future mediator and a specialist of school mediation services supposes formation of the mediation competence in the field of productive communication when considering legal issues and applying the psychology of conflict management in education.

When implementing the applied aspects of training mediators for education and the social sphere, the authors of the present article were guided by the model of mediation competence by V.V. Boyko, in which communicative, information and analytical, organisational and managerial, as well as emotional competencies are emphasised.

Mastering a new type of professional activity of a mediator for education and the social sphere supposes the formation of all the aforementioned components of the mediation competence. This gives a future mediator an opportunity to apply technologies of alternative dispute resolution, prepares for a value-based understanding of the causes of conflict, and forms a willingness to act as a mediator in negotiations in education and the social sphere.

There is a contradiction between conflictogenity of the educational environment of a multicultural region and the need for qualified mediators in education and the social sphere, whose professional training is implemented with the use of applied aspects in the mediation competence formation.

The mediation competence formation among specialists is a complex systemic process. Its success depends on understanding the process and the possibility of carrying out professional tests for practicing specific mediation techniques in education and the social sphere, which comprise the system of the professional activity a mediator. Several components: regulatory, communication, organisational, didactic, reflective, creative, and managerial can be distinguished in this system.

It is possible to solve the above contradiction through the implementation of the educational process on the basis of a practice-oriented programme for retraining mediators for education and the social sphere of the Centre for Mediation in Education of the School of 
Education, Psychology and Sociology of Siberian Federal University, in the networking cooperation between educational organisations and professional communities to form the professional competence of future mediators and specialists of mediation services. The retraining programme considers the needs of the multinational Siberian society and is aimed at solving regional problems in education and the social sphere (Smolyaninova, Korshunova, 2019).

\section{Theoretical framework}

The authors highlight person-oriented, activity-based and systemic approaches as the methodological basis of the practice-oriented system of retraining mediators.

T.A. Dmitrenko (Dmitrenko, Obraztsov, 2002) and P.I. Obraztsov (Obraztsov et al., 2004) state that practice-oriented training involves the use of professionally-oriented learning technologies and techniques for modelling fragments of future professional activity based on the use of the opportunities of contextual (professionally directed) study of core and noncore disciplines.

F.V. Sharipov (Sharipov, 2012) draws attention to the fact that the priority goal of practice-oriented training is to develop students' abilities and readiness for practical work, skills necessary in various areas of professional activity, and to achieve understanding of why these skills have been formed, and where and how they are used in real practice.

V.V. Kraevsky interprets professional retraining through acquisition of professional knowledge, abilities and skills. He emphasises that the complex of the acquired knowledge and specific skills is not always enough to perform professional functions in education and the social sphere. Consequently, acquisition of certain knowledge, abilities and skills is a necessary, but not the only condition for high-quality students training. The main thing in determining quality is the orientation of vocational training to specific practical activities (Berezhnova, Kraevsky, 2007).

In the study by V.D. Shadrikov (Shadrikov, 2004), a practice-oriented approach to training is interpreted as a system that improves the quality of professional training of future specialists through the application of the practical component of the educational process. This means that any knowledge that is significant for a specialist is mastered through practical activity.

O.P. Shabanova (Shabanova, Shabanova, 2015) believes that the level of qualification training of a future specialist should be determined by the joint work of an educational institution and a potential employer. The lack of employers' representatives supervising the practical part of training, as well as weak practical base and their conditional nature do not allow graduates to carry out professional activities in a quality manner.

The faculty of the School of Education, Psychology and Sociology activate the applied aspect of the retraining process for future specialists. The authors of the present article support the point of view of V.A. Guruzhapov and A.A. Margosis, who believe that a practice-oriented approach contributes to the harmonisation of educational relations and bringing the training outcome in line with the requirements of the modern society. The quality of training specialists for education and the social sphere depends on the flexibility of the educational process regarding the inclusion of organisations, such as network partners, practitioners, and academic community representatives in its implementation (Guruzhapov, Margolis, 2014).

The article attempts to describe the experience of Siberian Federal University in the implementation of the applied aspects of the mediation competence formation in the process of professional retraining of mediators for education and the social sphere. The experience of applying a practice-oriented approach in the process of retraining future mediators is analysed in accordance with the competence requirements of the professional standard "Specialist in The Field of Mediation (Mediator)" $"$.

\footnotetext{
2 Order of the Ministry of Labour and Social Protection of the Russian Federation of December 15, 2014 No. 1041H "On Approval of The Professional Standard 'Specialist in The Field of Mediation (Mediator)"'. Available at: https://pro.isoedu.ru/upload/STANDARTI/07/07.001.pdf (accessed 7 August 2020).
} 


\section{Methods}

Questionnaires and interviews of the educational process participants, the automated communicative competence testing by L. Michelson (modified by Yu.Z. Gil'bukh), the communicative tolerance questionnaire (V.V. Boyko), the authors' questionnaire for measuring information and analytical competence, the methodology by N. Hall "Evaluation of Emotional Intelligence", and the test "Communicative and Organisational Skills" (COS) have been used as research methods. A qualitative assessment of the educational process content at the university and determination of the level of the mediation competence formation among future specialists were organised with the financial support of the Russian Foundation for Basic Research within the framework of the implementation of the scientific project No. 18013-00528 "The Study of Mediation Practices in the Field of Education for Harmonisation of Interethnic Relations in A Multicultural Environment".

Two groups were involved in the study to identify the level of the mediation competence formation: practicing specialists of school mediation services (238 people - a control group) and master's students of the School of Education, Psychology and Sociology of Siberian Federal University in Krasnoyarsk and students of the professional retraining programme "Mediation. The Psychology of Conflict Management" (95 people - experimental group). The diagnostics was carried out in electronic format with the use of the materials of the "Communicative Competence" methodology (L. Michelson's testing, modified by Yu.Z. Gil'bukh), the communicative tolerance questionnaire (V.V. Boyko), diagnostics of the motivation for learning and emotional attitude to learning in secondary and high school (Ch. D. Spielberger's questionnaire), "Memory Activation Through the Revival of Emotions" (method by S.A. Garibyan), the method by N. Hall "Evaluation of Emotional Intelligence", and "Communicative and Organisational Skills" (COS) test.

According to the results of primary diagnostics, both groups demonstrated a high degree of the communicative tolerance forma-



Fig. 1. Results of diagnostics of the communicative tolerance formation 
tion. Experimental group - 21 points; control group - 32 points (Fig. 1).

Analysing the results obtained, it can be concluded that the experimental group indicators are below the average value (7.5 points out of 15) for each block, this indicates of a high level of communicative tolerance.

The control group has the maximum number of points -7 for the first and the sixth blocks of communication skills.

For both groups, block 8 "Intolerance to a partner of communication's states of discomfort (illness, fatigue, lack of mood) "You are not tolerant of a physical or mental discomfort of another person" is equal to 0 , which means that the students of both groups are sympathetic to the state of health of another person.

At the same time, rather high indicators of the communicative competence formation have been obtained.

To determine the level of the information and analytical competence, an assessment of motivation for training and emotional attitude to training has been carried out $(\mathrm{Ch}$. D. Spielberger's questionnaire in the interpretation of A.M. Prikhozhan).

Diagnostic analysis has shown the following results:

The experimental group participants scored 35 points in total on the scale of cognitive activity, 25 points on the achievement motivation, 20 points on the anxiety scale, and 11 points on the anger scale. According to the formula for calculating cognitive activity, the total score is 29 , which indicates that in experimental group the $2^{\text {nd }}$ the level of cognitive activity is productive motivation, a positive attitude towards training and compliance with social standards.

Figure 2 shows the distribution of the experimental group scales' indicators as a percentage of the elements of information and analytical competence based on the Ch. D. Spielberger's questionnaire in the interpretation of A.M. Prikhozhan.

In the control group on the scale of cognitive activity the total score was 30 points, 31 points on the achievement motivation, 17 points on the anxiety scale, and 15 points on the anger scale. According to the formula for calculating cognitive activity, the total score is 29 , which indicates that the respondents in the control group also have the $2^{\text {nd }}$ level of cognitive activity - productive motivation, a positive attitude towards training and compliance with social standards.

Figure 3 demonstrates the results of diagnostics of information and analytical competence of the control group by scales (\%) based on Ch. D. Spielberger's questionnaire in the interpretation of A.M. Prikhozhan as a percentage.

The diagnostic data show that the information and analytical competence is sufficiently developed among the respondents of both groups. There are differences only within the

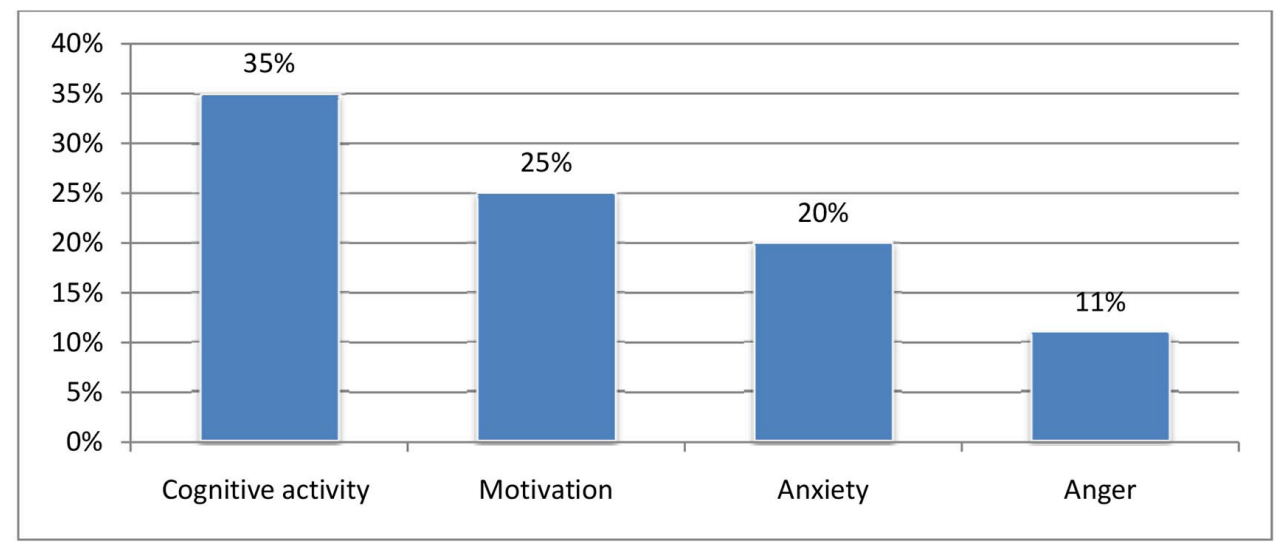

Fig. 2. Results of diagnostics of the information and analytical competence of the experimental group by scales (\%) based on Ch.D. Spielberger's questionnaire in the interpretation of A.M. Prikhozhan 




Fig. 3. Results of diagnostics of information and analytical competence of the control group by scales (\%) based on Ch.D. Spielberger's questionnaire in the interpretation of A.M. Prikhozhan

scales, and they should be considered when developing a new retraining programme.

The adapted methodology "Memory Activation Through the Revival of Emotions" (adapted method by S.A. Garibyan) was used when diagnosing the mnemonic competence.

The respondents were offered to listen to the words, and then write them down from memory. Qualitative analysis has demonstrated that words with subjective meaning (special emotiogenicity for the respondents) are remembered better. For instance: love, meeting, endof-term exams, scholarship, etc.

The method by S.A. Garibyan is based on the associative method and the use of emotions. It is necessary to note that $64 \%$ of the respon- dents in the control group reproduced $59.7 \%$ of the words and that the words with special emotiogenicity for the respondents are remembered better.

Interpretation of the experimental group results has shown that $10 \%$ of the respondents reproduced $83 \%$ of the phrases proposed. The rest of the respondents $(90 \%)$ demonstrated results ranging from $9 \%$ to $47 \%$.

Diagnostics of the emotional competence according to N. Hall's method gives an opportunity to assess emotional intelligence, reveal the ability to understand a person's relationships represented in emotions and manage the emotional sphere based on decision-making. The data for both groups are shown in Fig. 4.

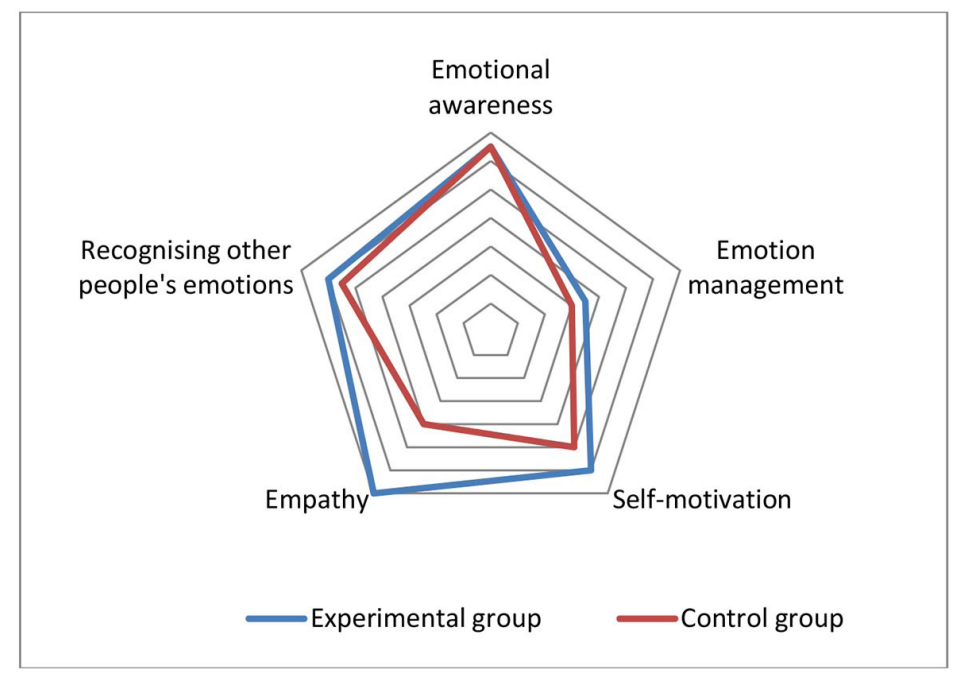

Fig. 4. The results of the emotional competence diagnostics according to the method by N. Hall 
Hence it is possible to conclude that in both groups "Emotional awareness" is developed at the same average level; it is necessary to pay attention to the scale "Emotion management" since it is formed at a low level in both groups; the "Empathy" scale in the experimental group is formed at a high level - 14 points, other scales are formed in both groups, also at the average level, their value varies from 10 to 12 points.

Diagnostics of the organisational and managerial competence was carried out with the use of the COS test (Method for The Study of Communicative and Organisational Skills). This method gives an opportunity to identify the level of organisational and communicative skills formation among the respondents.

According to the analysis of the COS test data from the experimental group the obtained result of 0.65 indicates of the $3^{\text {rd }}$ average level of communicative skills formation. The result of organisational skills diagnostics of 0.7 also shows the average level of these skills manifestation.

The control group results on the communicative skills formation is 0.3 , which refers to the $1^{\text {st }}$ (low) level of communicative skills. The indicator of organisational skills of 0.55 also detects the $1^{\text {st }}$ (low) level of the skills.

The data for both groups are shown in Fig. 5.

Based on the main results of the mediation competence formation among specialists for education and the social field in the process of professional retraining, it can be concluded that no significant differences in the competencies formation in the experimental and control groups have been found.

Analysing all the data on the formation of competencies that are included in the mediation competence, it can be concluded that it is necessary to form the mnemonic competence for the experimental group respondents. Other competencies are developed at an average level for each of the diagnostic scales, which allows them to carry out mediation procedures. Based on the data of a comparative analysis regarding cognitive activity formation in both groups, it can be concluded that productive motivation, a positive attitude towards training, and compliance with the social standard correspond to the average level. It is necessary to take it into



Fig. 5. Results of the organisational and managerial competence diagnostics based on the COS test 
account and elaborate it as part of supervision with the participation of a practicing mediator. Diagnostic data indicate that information and analytical competence is equally formed among the respondents of the control and experimental groups, which is quite expected for the age category of the retraining programme students.

The analysis of the specific features of the formation of individual components of the mediation competence among specialists for education and the social sphere gives an opportunity to draw the following conclusions.

Firstly, in the process of the retraining programme implementation, special attention should be paid to the formation of the emotional competence and the information and analytical competence, as important components of mediation competence.

Secondly, to form the information and analytical competence of future mediators for education and the social sphere, the fulfilment of reflective tasks based on the results of the distributed practice should be provided in the curriculum. The participation of an employer's representative as a supervisor in the process of performing and defending reflective tasks will contribute to the development of professional skills to retain important facts in the mediation procedure.

Thirdly, the implementation of a practice-oriented approach in the process of retraining mediators for education and the social sphere will give an opportunity to form the ability and readiness to perform the professional functions of a mediator, taking into account understanding of the specific features of conflicts in education and the social sphere during the training process. Thus, organising the process of the emotional competence formation among future mediators for education and the social sphere in the process of retraining according to the programme "Mediation. The Psychology of Conflict Management", we contribute to their professional development and adaptation to the mediation procedure in the context of the implementation of quasi-professional activities with the participation of employers as supervisors and experts.

\section{Discussion}

The practice-oriented approach in its basic meanings and focus reflects the main processes of education modernisation, which are based on training of professionally competent graduates; as for future mediators in the field of education (Smolyaninova, 2019) they should be able to quickly adapt to the conditions of specific practical activities, be professionally mobile and perceive a wide range of various professional information. Only a practicing specialist can fully manifest mediation competence, but it is formed during the period of study on the retraining programme at the university.

To describe the signs of the competence manifestation, the taxonomy of target results of education - to know, to be able, to own - is used. To choose the content of training, structuring of each competence is used as components of mediated competence according to V.V. Boyko, that is, levels of knowledge, abilities, and possession are distinguished in each competence.

Thus, representatives of network partners and employers become full-fledged participants of the educational process, are actively involved in the master's programme implementation, and act as experts and supervisors. Professional training of future mediators is distinguished by an increase in practical classes and workshops, distributed, continuous practice on the basis of school mediation services is being implemented, supervision by practicing mediators and representatives of employers in the region is carried out on a regular basis.

Feedbacks of network partners in the process of professional tests reflection allows to form an idea of the results of professional activity and academic performance of the retraining programme students, which gives an employer an opportunity to regularly monitor the quality of future mediators training and observe the process of their professional development.

Such principles as continuity, eventfulness, network interaction, supervision of professional action tests, and continuity of the results of formal and non-formal education were selected and implemented in the process of training future mediators for education and the social sphere as the leading pedagogical principles. 
The principle of continuity is implemented in the sequential development and application of mediation practices in the process of studying various disciplines, when preparing final qualification work and during pedagogical practices.

Professional activity supervision provides for a detailed analysis of specific conflict situations and probable solutions, professional cases from practicing mediators and employers' representatives. Individual and collective supervision helps to critically assess possible actions of a specialist and consequences of different ways of resolving conflicts in education and the social sphere.

The principle of eventfulness ensures professional activity of a mediator in specific life situations. Components of productive training of the professional development of a mediator include consideration of the causes of each conflict, finding all the participants and parties of the conflict, thinking over and discussing the possible ways to resolve the conflict and consequences of the conflict with colleagues.

Participation of network partners and practicing mediators in conducting interactive classes, watching and discussing videos of mediation meetings and attending practicing specialists' consultations are presented as professional tests of future mediators.

Along with studying at the university, many students of the retraining programme independently master additional courses and workshops, both contact and distance ones. The workshops allow to study important features of the mediation procedure and develop professional skills in conducting mediation procedures with practicing mediators. Using the results of non-formal education in the content of the retraining programme for mediators contributes to expanding the range of components of their practical and professional activity as mediators.

\section{Experience of implementing practices and educational events in the context of network interaction of educational organisations and professional communities}

Professional retraining of mediators involves organisation of training with the use of innovative practice-oriented technologies.

An important component for the regional education system development and training of specialists for school mediation services is implementation of the practice-oriented retraining programme "Mediation. The Psychology of Conflict Management", which provides for networking with civil society institutions and educational institutions of the Krasnoyarsk Krai, on the basis of the federal university.

The retraining programme is focused on strengthening practical training of future mediators in accordance with international and professional standards, increasing the share of practices implemented in network interaction with partners on the basis of school mediation services. It is necessary to note the possibility of building individual educational routes, implementation of practices with the participation of network partners, and assessment of educational results based on the e-portfolio technology as advantages of the retraining programme.

The content and organisational and pedagogical conditions of the professional retraining of future mediators in accordance with international and professional standards is a motivational basis for increasing school mediation services efficiency. Despite the extensive description of the challenges of organising mediators training for education and the social sphere in theoretical and applied research, it remains understudied. Thus, the study of the process of the mediation competence formation among school mediation services specialists is determined by the need to introduce applied aspects of psychological and pedagogical methods of personal and professional development of future mediators into educational practice.

When considering the basic principles and various approaches in mediation, a discussion with the obligatory use of examples from real school life is held with the retraining programme students.

The method of principled negotiations (by R. Fisher and W. Ury) and the concept of mediation (by Lincoln) are studied in the business game format.

Mastering models of process-oriented mediation (understanding and agreement) and 
result-oriented mediation (agreement and contract) takes place with the preparation and subsequent discussion of cases.

The issues of using mediation in the field of management deserve special attention. Personal experience of training and professional activity in teaching teams allows students to reasonably express their point of view and offer an optimal solution to conflict situations associated with managerial decisions. Issues of corporate culture are emotionally discussed in teaching teams, where interpersonal conflicts arise.

Intrapersonal conflicts are of particular importance of all pedagogical challenges in the field of education. To be able to recognise students' tension, to find the conditions for a conflict occurrence, to choose adequate ways to resolve a person's internal contradictions is an important quality of a teacher-mediator.

The study of stress, causes of its occurrence, signs of stress tension and ways to relieve stress is carried out with the active use of special techniques and exercises.

In the process of studying the theory and practice of mediation, the retraining programme students are offered to write an essay - an independent reflection on the topic "Causes of Conflict." Active practical mastering of the basic methods of conflicts settlement and resolution, the choice and use of mediation practices in the classroom gives the programme students an opportunity to test and evaluate the effectiveness of each technique necessary for their future professional activity.

\section{Conclusion}

Professional retraining of mediators includes general education courses and a professional component. At the same time, the main methods of the practice-oriented training are: project-based learning technology ("the one hour project", long-term project, interdisciplinary project, project integrated into another area of training, working on several projects, and international project); participation in professional competitions; interdisciplinary interaction; participation of employers in the educational process; annual update of professional cases based on real practice. In this way, implementation of the practice-oriented approach contributes to the improvement of the existing educational programmes and technologies for retraining mediators with a qualitatively new level of mediation competence, ready for professional activity in modern conditions.

Implementation of a practice-oriented approach for the formation of the professional competence of mediators contributes to the improvement of the quality of work of school mediation services and, as a result, ensures creation of a conflict-free regional educational environment. It seems promising to consider the possibility of creating an Internet community of professional mediators to exchange experience, inclusion of network partners in the process of training specialists-mediators, distant participation of practicing mediators and employer representatives as supervisors in the process of resolving complex conflict situations.

It should be noted that it is necessary to update the competencies of the Federal State Educational Standard of Higher Education 3+ for pedagogical areas in terms of the mediation competence formation. Organisation of the communicative activity of the pedagogical communication participants is of particular interest, since under the influence of the educational environment conflictogenity, the greatest changes affect precisely this aspect of teachers' professional activity.

\section{References}

Andronnikova, O.O., Radzikhovskaya, O.E. (2020). Victimological Aspects of The Development of Restorative Mediation Practices in A Multicultural Society: Problems, Needs, Development Prospects. In Journal of Siberian Federal University. Humanities and Social Sciences, 13 (2), 158-166. DOI: 10.17516/1997-1370-0547.

Berezhnova, E.V., Kraevsky, V.V. (2007). Issledovaniia v oblasti obrazovaniia: problemy upravleniia kachestvom: monografiia [Research in Education: Quality Management Challenges: Monograph]. Moscow, RAO, $150 \mathrm{p}$. 
Dmitrenko, T.A., Obraztsov, P.I. (2002). Professional'no-orientirovannye tekhnologii v sisteme vysshego pedagogicheskogo obrazovaniia kak pedagogicheskaia problema [Professionally-Oriented Technologies in The System of Higher Pedagogical Education as A Pedagogical Problem]. In Vestnik vysshei shkoly Alma Mater [Higher School Herald Alma Mater], 7, 55-56.

Guruzhapov, V.A., Margolis, A.A. (2014). Proektirovanie modeli praktiko-orientirovannoi podgotovki pedagogicheskikh kadrov na osnove setevogo vzaimodeistviia obrazovatel'nykh organizatsii, realizuiushchikh programmy vysshego obrazovaniia i nachal'nogo obshchego obrazovaniia [Designing Models of Practice-Oriented Undergraduate Training Program in Psychological and Pedagogical Education (Primary School Teacher) Based on Networking of Educational Institutions, Implementing Higher Education and Primary Education Programs]. In Psikhologicheskaia nauka i obrazovanie [Psychological Science and Education], 19 (3), 143-159.

Interregional Public Centre "Judicial and Legal Reform" (2020). Available at: http://sprc.ru (accessed 7 August 2020).

Obraztsov, P.I., Vilensky, M.Ya., Uman, A.I. (2004). Tekhnologii professional'no-orientirovannogo obucheniia v vysshei shkole: uchebnoe posobie [Technologies of Vocationally Oriented Training in Higher Education: Coursebook]. Moscow, Pedagogicheskoe obshchestvo Rossii, 144 p.

Order of The Ministry of Labour and Social Protection of The Russian Federation of December 15, 2014 No. 1041н "On Approval of The Professional Standard 'Specialist in The Field of Mediation (Mediator)"”. Available at: https://pro.isoedu.ru/upload/STANDARTI/07/07.001.pdf (accessed 7 August 2020).

Rasporiazhenie ot 25 avgusta 2014 goda №1618-r. V sootvetstvii s Natsional'noi strategiei deistvii v interesakh detei [Order of August 25, 2014 No. 1618-p. In line with The National Plan of Action for Children]. Available at: http://government.ru/docs/14494 (accessed 7 August 2020).

Shabanova, O.P., Shabanova, M.N. (2015). Praktiko-orientirovannaia podgotovka pedagoga kak strategiia rossiiskogo obrazovaniia [Practice-Oriented Teacher Training as Russian Education Strategy]. In Uchenye zapiski [Scientific Notes], 1 (33), 123-127.

Shadrikov, V.D. (2004). Novaia model' spetsialista: innovatsionnaia podgotovka i kompetentnostnyi podkhod [The New Specialist Model: Innovative Training and Competence-Based Approach]. In Vysshee obrazovanie segodnya [Higher Education Today], 8. 3-8.

Sharipov, F.V. (2012). Pedagogika i psikhologiia vysshei shkoly: uchebnoe posobie [Pedagogy and Psychology of Higher Education: Coursebook]. Moscow, Logos, 448 p.

Smolyaninova, O.G. (2019). Training Model of School Intercultural Mediators Master's Programme at Siberian Federal University. In Proceedings of the $13^{\text {th }}$ International Technology, Education and Development Conference "ITED2019". Valencia, 1991-1997.

Smolyaninova, O.G., Korshunova, V.V. (2019). Otnoshenie uchastnikov obrazovatel'nogo prostranstva Krasnoiarskogo Kraia k mediativnym praktikam [Attitude of Participants in The Educational Space of The Krasnoyarsk Krai to Mediation Practices]. In Science for Education Today, 9 (3), 7-27. DOI: 10.15293/26586762.1903.01. 


\title{
Опыт реализации практико-ориентированной программы переподготовки медиаторов для образования и социальной сферы
}

\author{
В.В. Коршунова, Е.А. Биркун \\ Сибирский федеральный университет \\ Российская Федерация, Красноярск
}

\begin{abstract}
Аннотация. Актуальность данного исследования подтверждена заказом на переподготовку специалистов для образования и социальной сферы, способных выступать в качестве посредника и формировать культуру мирного разрешения конфликтов в поликультурной среде. В статье проведен анализ и выделены запросы работодателей на формирование медиативной компетентности у участников образовательного пространства Красноярского края.

В этом контексте авторами раскрыты практические аспекты формирования медиативной компетентности в процессе профессиональной подготовки в федеральном университете будущих медиаторов и сотрудников школьных служб медиации.

На основе анализа специфики профессиональной деятельности медиатора, результатов анкетирования специалистов социальной сферы, опыта подготовки студентов педагогических направлений в федеральном университете предложена модель практико-ориентированной программы переподготовки медиаторов для образования и социальной сферы Красноярского края. Программа реализуется на базе Центра медиации в образовании ИППС СФУ, в сетевом взаимодействии образовательных организаций и профессиональных сообществ. Данная программа переподготовки учитывает запросы многонационального сибирского социума, направлена на решение региональных проблем в образовании и социальной сфере.

Программа переподготовки построена на принципах: непрерывности, супервизии профессиональной деятельности, событийности образовательного процесса, проб профессионального действия, преемственности результатов формального и неформального обучения.

Подготовка будущих медиаторов в рамках программы переподготовки «Медиация. Психология управления конфликтом» осуществляется по модульному учебному плану, в котором увеличена доля практических занятий, организована научноисследовательская деятельность студентов по проблемам продуктивной коммуникации в медиативной процедуре, реализуются профессиональные пробы в рамках распределенной практики.

Для формирования прикладных аспектов профессиональной компетентности будущих медиаторов и специалистов школьных служб примирения в образовательный процесс включены представители сетевых партнеров.

Прикладные аспекты подготовки будущих медиаторов и специалистов служб школьной медиации из числа педагогов помогают эффективно решать профессиональные задачи по организации бесконфликтного образовательного пространства и способствуют формированию культуры продуктивной коммуникации и урегулирования конфликтов.

Формирование медиативной компетентности участников образовательного процесса осуществлялось с применением методик измерения коммуникативной, информационно-аналитической, организационно-управленческой и эмоциональной компетенций.
\end{abstract}


Исследование проводилось с использованием Google-сервисов на протяжении 2019-2020 годов. Всего приняли участие 333 человека, из них работающие специалисты школьных служб медиации - 238 человек (контрольная группа), магистры ИППС СФУ г. Красноярска, слушатели программы профессиональной переподготовки «Медиация. Психология управления конфликтом» - 95 человек (экспериментальная группа).

Ключевые слова: медиация, компетенция, медиативная компетентность, профессиональное становление медиатора, переподготовка, урегулирование конфликта, рефлексия, прикладной аспект, практико-ориентированная программа.

Исследование выполнено при финансовой поддержке Российского фонда фундаментальных исследований в рамках научного проекта № 18-013-00528 «Исследование медиативных практик в сфере образования для гармонизации межнациональных отношений в поликультурной среде».

Научная специальность: 13.00.00 - педагогические науки. 